\title{
Determinants of Cryptocurrency Price Movements
}

\author{
Dilek Teker ${ }^{1}$, Suat Teker $^{2}$ and Mustafa Ozyesil ${ }^{3}$ \\ ${ }^{1}$ Is1k University, Department of Business, \\ ${ }^{2}$ Is1k University, Department of Economics, \\ ${ }^{3}$ Istanbul Aydin University, Department of Business Administration,
}

\begin{abstract}
Cryptocurrency is a recent and popular topic that attracts the interest of investors and fund managers. Beyond the market discipline, researchers question the interaction between cryptocurrecies and macroeconomic variables. This study we focus on how the changes in gold and oil prices effect the daily price movements of different cryptocurrencies. The daily database includes prices of the cryptocurrencies of Bitcoin, Tether, Ethereum Litecon and EOS for the period between August 1, 2017 and April 3, 2019. Initially the stationarity of the series is tested by $\mathrm{Ng}$ and Perron (2001) method. The existence of the cointegration relationship between the series is tested by Johansen (1988) technique. The presence of causality relationships between the series is investigated with the Dolado and Lütkepohl (1996) causality test. The paper explains the details of the empirical findings.
\end{abstract}

Keywords: Cryptocurrency, Stationarity, Cointegration, Vector Error Correction

\section{Introduction}

Cryptocurreny market has a recent increasing popularity. The recent discussions rely on whether a cryptocurrency is really an exchange tool or aan alternative investment instrument. Among the others; Bitcoin has the highest market value and a sharp increase in value in the recent years. However the unpredictable volatility makes it a mysterious instrument. The financial markets watch the sharp increase of Bitcoin with a severe skepticism. Not only Bitcoin but also the other cryptocurrencies are different from a fiat currency. A fiat currency is backed by the full credit of its government. The issuance of a fiat currency is supervised by the nation's central bank. On the other hand, the value of a Bitcoin is determined by how much the investors are willing to pay for it. Various studies try to explain the price movements of cryptocurrencies and economic factors influence the volatility of these tools. Altough majorly the dependent variable is Bitcoin, some researchers make comparisons regarding other cryptocurrencies. Bouoiyour et al. (2015) explain Bitcoin as one of the most innovative financial tool while as some other researchers . Bouoiyour and Selmi (2015) criticise it due to unpredictible volatility in the market. Since Bitcoin is observed as volatile; it is susceptible to speculative bubbles than other currencies (Grinberg, 2011). Hence, Bitcoin has a popularity in the financial markets and in portfolio management (Dyhrberg, 2016). Roy et all (2018) uses autoregressive integrated moving average (ARIMA) models to explain Bitcoin volatility. Katsiampa (2017) explore the optimal conditional heteroskedasticity model with regards to goodness-of-fit to Bitcoin price data using AR-GARCH AR-EGARCH AR-TGARCH AR-APARCH AR-CGARCH AR-ACGARCH models. The empirical results indicates AR-CGARCH as the best model that explains volatility. Stavroyiannis and Babalos (2017) used univariate and multivariate GARCH models and vector autoregressive specifications to explain the Dynamics of Bitcoin. Cermak (2017) used a GARCH $(1,1)$ to model Bitcoin's volatility movements with regard to several macroeconomic indicators. He targeted the countries where Bitcoin has a high trading volume. Chen et al. (2016) used different GARCH models to predict the volatility. Based on information criterion such as AIC and BIC; TGARCH $(1,1)$ model was found to be the optimal model. Naimy and Hayek (2018) compared the predictive ability of volatility forecasts estimated by GARCH and EGARCH models. According to their findings, the EGARCH $(1,1)$ model outperforms the GARCH $(1,1)$ and EWMA models in both in 
sample and out of sample contexts with increased accuracy in the out of sample period. Chu et al. (2017) fitted 12 GARCH-type models to seven major cryptocurrencies. El Bahrawy and Alessandretti (2017) examine behaviour of 1469 cryptocurrencies in the period between April 2013 and May 2017. They find that cryptocurrencies appear and disappear continuously and their market capitalization is increasing exponentially. Poyser (2017) explains the indicators affect the movements of cryptocurrencies as external and internal factors. These indicators are mainly explained as popularity and legalization as internal factors; interest rates, stock markets and gold prices as external factors.

\section{Data \& Methodology}

This study focus on the interaction of oil and gold prices in the daily price movements of each cryptocurrency. Among the cryptocurrencies; Bitcoin, Tether, Ethereum, Litecoin and EOS are selected since these 5 have the highest market values. The database includes the daily prices (in USD) in the period between August 1, 2017 and April 3, 2019. The logged data is used in the models. Not checking the stationarity degrees of the series, may result incorrect findings (Elder and Kennedy, 2001). Therefore, initially the stationarity is tested with $\mathrm{Ng}$ and Perron (2001) method. This test was especially developed to correct the problem of size distortion in the volume of error term in Phillips and Perron (1988) test. This method was preferred in the study because it is more powerful than ADF and PP tests (Charles, Darne and Tripier, 2018). In the study, Ng - Perron (2001) unit root tests were performed and the results obtained are presented in Table 1.

Table I: Unit Root Test Results

\begin{tabular}{|c|c|c|c|c|c|c|c|c|}
\hline & \multicolumn{4}{|c|}{ Level Values } & \multicolumn{4}{|c|}{ First Difference } \\
\hline & $M Z_{\alpha}$ & $M Z_{t}$ & $M S B$ & $M P T$ & $M Z_{\alpha}$ & $M Z_{t}$ & $M S B$ & $M P T$ \\
\hline LnBIT & -3.12 & -1.21 & 0.39 & 28.49 & $-166.16^{* * *}$ & $-9.05 * * *$ & $0.05 * * *$ & $0.23 * * *$ \\
\hline LnTET & -16.63 & -2.04 & 0.41 & 5.55 & $-206.34 * * *$ & $-10.13^{* * *}$ & $0.04 * * *$ & $0.14 * * *$ \\
\hline LnETH & -1.47 & -0.83 & 0.56 & 58.94 & $-219.23 * * *$ & $-10.44 * * *$ & $0.04 * * *$ & $0.15^{* * *}$ \\
\hline LNLIT & -3.41 & -1.30 & 0.38 & 26.67 & $-165.45 * * *$ & $-9.05 * * *$ & $0.05 * * *$ & $0.21 * * *$ \\
\hline LnEOS & -2.35 & -1.07 & 0.45 & 38.13 & $-285.19 * * *$ & $-11.89 * * *$ & $0.04 * * *$ & $0.13^{* * *}$ \\
\hline LnGOLD & -4.65 & -1.52 & 0.32 & 19.59 & $-68.26^{* * *}$ & $-5.83 * * *$ & $0.08 * * *$ & $0.37 * * *$ \\
\hline LnOIL & -3.52 & -1.26 & 0.35 & 24.83 & $-166.59 * * *$ & $-9.12 * * *$ & $0.05 * * *$ & $0.15^{* * *} *$ \\
\hline \multicolumn{9}{|c|}{ Critical Values } \\
\hline & $M Z_{\alpha}$ & $M Z_{t}$ & $M S B$ & $M P T$ & $M Z_{\alpha}$ & $M Z_{t}$ & $M S B$ & $M P T$ \\
\hline$\% 1$ & -23.80 & -3.42 & 0.14 & 4.03 & -13.80 & -2.58 & 0.17 & 1.78 \\
\hline$\% 5$ & -17.30 & -2.91 & 0.16 & 5.48 & -8.10 & -1.98 & 0.23 & 3.17 \\
\hline
\end{tabular}

Note: $* * *$ indicates that the series is stationary at $1 \%$ significance level. Optimal delay lengths were determined according to the modified Akaike criteria. Tests with constant terms and trend were used for the level values of the series and only fixed terms test methods were used for the first differences.

It is observed that the series become stationary when the data is differenced. This type of econometric series is called I (1) series (Dikmen, 2012). In this case; during the analysis period, it can be said that there were significant fluctuations in the prices of crypto currencies, gold and oil. The unit root tests are followed by the existence of cointegration relationship between the series can be tested by Engle and Granger (1987) or Johansen (1988) method (Tar1, 2012: 415-432). Engle and Granger (1987) method gives effective results in models with single explanatory variables, while Johansen 
(1988) method should be used in models with multiple explanatory variables (Kremers, Ericsson and Dolado, 1992). Johansen (1988) H0 hypothesis of the cointegration test "There is no cointegration relationship between the series". To perform Johansen (1988) the cointegration test, a standard (unrestricted) VAR model must be estimated and the optimum lag length must be determined. The optimal lag lengths are as LnBIT (2), LnTET(4), LnETH(2), LnLIT(2), LnEOS(2). Johansen (1988) cointegration test was performed separately for each crypto currency model using the optimum lag and the results are presented in Table 2.

Table II: Cointegration Test Results

\begin{tabular}{|c|c|c|c|c|c|c|}
\hline $\begin{array}{c}\text { The dependent } \\
\text { variable }\end{array}$ & Ho $_{0}$ Hypothesis & $\begin{array}{c}\text { Trace } \\
\text { Statistics } \\
\end{array}$ & $\begin{array}{c}\begin{array}{c}\text { Probability } \\
\text { Value }\end{array} \\
\end{array}$ & $\begin{array}{c}\text { Max-Eigen Value } \\
\text { Statistics }\end{array}$ & $\begin{array}{c}\text { Probability } \\
\text { Value }\end{array}$ & Decision \\
\hline \multirow{3}{*}{ BITCOIN } & None & 22.15 & 0.58 & 9.57 & 0.86 & \multirow{3}{*}{ No Cointegration } \\
\hline & Up to 1 & 12.58 & 0.39 & 8.14 & 0.53 & \\
\hline & Up to 2 & 4.44 & 0.35 & 4.44 & 0.35 & \\
\hline \multirow{3}{*}{ TETHER } & None & $31.72 * *$ & 0.02 & $22.62 * *$ & 0.03 & \multirow{3}{*}{$\begin{array}{c}\text { There is } \\
\text { Cointegration }\end{array}$} \\
\hline & Up to 1 & 9.09 & 0.35 & 5.90 & 0.62 & \\
\hline & Up to 2 & 3.19 & 0.17 & 3.19 & 0.17 & \\
\hline \multirow{3}{*}{ ETHEREUM } & None & 20.05 & 0.41 & 9.44 & 0.79 & \multirow{3}{*}{ No Cointegration } \\
\hline & Up to 1 & 10.60 & 0.23 & 7.60 & 0.41 & \\
\hline & Up to 2 & 2.99 & 0.18 & 2.99 & 0.18 & \\
\hline \multirow{3}{*}{ LITECOIN } & None & 20.93 & 0.66 & 8.39 & 0.93 & \multirow{3}{*}{ No Cointegration } \\
\hline & Up to 1 & 12.54 & 0.40 & 7.36 & 0.62 & \\
\hline & Up to 2 & 5.18 & 0.26 & 5.18 & 0.26 & \\
\hline \multirow{3}{*}{ EOS } & None & 20.59 & 0.38 & 11.26 & 0.62 & \multirow{3}{*}{ No Cointegration } \\
\hline & Up to 1 & 9.33 & 0.33 & 6.34 & 0.56 & \\
\hline & Up to 2 & 2.98 & 0.18 & 2.98 & 0.18 & \\
\hline
\end{tabular}

Note: $* *$ indicates the presence of cointegration at the $5 \%$ significance level in the relevant model.

When the test results in Table 3 are examined, it is seen that there is a cointegration relationship between the series at the 5\% significance level in the model where only the dependent variable is Tether, and in the other models no cointegration between series is detected. In this case, the analysis with the level values of the series in the model where only the dependent variable is Tether will not include spurious regression problem and will be reliable. Therefore, only long and short term analyzes were performed for this model. Finally, the causality relationships between the series were investigated by Dolado and Lütkepohl (1996) causality test. Like Toda-Yamamoto (1995), the causality test of Dolado and Lütkepohl (1996) refers to the Toda and Yamamoto (1995) approach and applies to the level values of the series. In this respect, it is more powerful than Granger (1969) causality test (Şentürk and Akbaş, 2012). The H0 hypothesis of this test is that "there is no causal relationship from the first variable to the second variable". In the study, the presence of causality relationships between the series in the models were analyzed by using Dolado and Lütkepohl (1996) causality test based on the optimal lag lengths in Table 2 and the results obtained are presented in Table 3. 
Table III: Causality Test Results

\begin{tabular}{|c|c|c|c|}
\hline $\mathrm{H}_{0}$ Hypothesis & Chi-Square Statistics & Probability Value & Decision \\
\hline $\ln G O L D \nrightarrow L n B I T$ & 0.45 & 0.92 & Yok \\
\hline $\operatorname{LnBIT} \nrightarrow \operatorname{LnGOLD}$ & 1.75 & 0.62 & Yok \\
\hline $\operatorname{LnOIL} \nrightarrow \operatorname{LnBIT}$ & $6.65^{*}$ & 0.08 & Var \\
\hline LnBIT $\nrightarrow$ LnOIL & 2.93 & 0.40 & Yok \\
\hline $\operatorname{lnGOLD} \nrightarrow$ LnTET & 1.60 & 0.90 & Yok \\
\hline $\operatorname{LnTET} \nrightarrow \operatorname{LnGOLD}$ & 2.58 & 0.76 & Yok \\
\hline LnOIL $\nrightarrow$ LnTET & 7.43 & 0.19 & Yok \\
\hline LnTET $\nrightarrow$ LnOIL & 6.83 & 0.23 & Yok \\
\hline $\ln G O L D \nrightarrow \operatorname{LnETH}$ & 1.61 & 0.65 & Yok \\
\hline LnETH $\nrightarrow$ LnGOLD & 2.03 & 0.56 & Yok \\
\hline LnOIL $\nrightarrow$ LnETH & 5.92 & 0.11 & Yok \\
\hline LnETH $\nrightarrow$ LnOIL & $6.92 *$ & 0.07 & Var \\
\hline $\operatorname{lnGOLD} \nrightarrow \mathrm{LnLIT}$ & 0.28 & 0.96 & Yok \\
\hline LnLIT $\nrightarrow$ LnGOLD & $6.74 *$ & 0.08 & Var \\
\hline LnOIL $\nrightarrow$ LnLIT & 5.74 & 0.12 & Yok \\
\hline LnLIT $\nrightarrow$ LnOIL & $7.24 *$ & 0.06 & Var \\
\hline InGOLD $\nrightarrow$ LnEOS & 5.81 & 0.12 & Yok \\
\hline LnEOS $\nrightarrow$ LnGOLD & 1.21 & 0.75 & Yok \\
\hline LnOIL $\nrightarrow$ LnEOS & 0.78 & 0.85 & Yok \\
\hline LnEOS $\nrightarrow$ LnOIL & $7.67 *$ & 0.05 & Vat \\
\hline
\end{tabular}

Note: $*$ indicates the presence of causality relationship at the $10 \%$ significance level from the first variable to the second variable in the relevant line.

Table 3 shows that there are unidirectional causality relationships with a $10 \%$ significance level from oil to Bitcoin, from Litecoin to Gold, from Ethereum, Litecoin and EOS to oil.

\section{Conclusion}

This study we focus on how the changes in gold and oil prices effect the daily price movements of different cryptocurrencies. Bitcoin, Tether, Ethereum Litecon and EOS are selected from the cryptocurrency list. The daily logged and differenced data is used for the period between August 1, 2017 and April 3, 2019. The cointegration test results show a cointegration relationship between the series at the 5\% significance level in the model where only the dependent variable is Tether. So we did not find a cointegrated relation between oil and gold prices for Bitcoin, Ethereum Litecon and EOS. Furthermore, the causality tests imly a result of unidirectional causality relationships with a $10 \%$ significance level from oil to Bitcoin, from Litecoin to Gold, from Ethereum, Litecoin and EOS to oil.

\section{References}

[1] Bouoiyour J. and R. Selmi (2015a). Bitcoin Price: Is it really that New Round of Volatility can be on way? https://mpra.ub.uni-muenchen.de/65580/1/MPRA_paper_65580.pdf

[2] Cermak, V. (2017). Can Bitcoin Become a Viable Alternative to Fiat Currencies? An Empirical Analysis of Bitcoin's Volatility Based on a GARCH Model. SSRN Electronic Journal. 10.2139/ssrn.2961405.

https://doi.org/10.2139/ssrn.2961405 
[3] Charles, A., Darne, O. and Tripier, F. (2018). Uncertainty and the Macroeconomy: Evidence from an Uncertainty Composite Indicator. Applied Economics, 50(10), 1093-1107. https://doi.org/10.1080/00036846.2017.1349294

[4] Çütçü, İ. ve Kılıç, Y. (2018). Bitcoin Fiyatları ile Dolar Kuru Arasındaki İlişki: Yapısal Kırılmalı Zaman Serisi Analizi. Yönetim ve Ekonomi Araştırmaları Dergisi, 16(4), 349-366. https://doi.org/10.11611/yead.474993

[5] Chu J., Chan S., Nadarajah S., Osterrieder J., (2017). GARCH Modelling of Cryptocurrencies. Journal of Risk and Financial Management, 10(4):17. https://doi.org/10.3390/jrfm10040017

[6] Dikmen, N. (2012). Ekonometri. (2. BAskı). Dora Yayınları, Bursa.

[7] Dolado, J. L. and Lütkepohl, H. (1996). Making Wald Tests Work for Cointegrated VAR Systems. Econometric Reviews, 15, 369-386. https://doi.org/10.1080/07474939608800362

[8] Dyhrberg A.H. (2016b). Bitcoin, gold and the dollar - A GARCH volatility analysis. Financial Research Letters., 16, pp. 85-92. https://doi.org/10.1016/j.frl.2015.10.008

[9] Grinberg R. (2011). Bitcoin: An innovative alternative digital currency Hastings Sci. Tech. LJ., 4, pp. 160211.

[10] Katsiampa P. (2017).Volatility estimation for Bitcoin:A comparison of GARCH models, Economics letters, 158(2017) 3-6.

https://doi.org/10.1016/j.econlet.2017.06.023

https://www.researchgate.net/profile/Refk_Selmi/publication/305810738_Bitcoin_A_beginning_of_a_new_ phase/links/57a2f6da08aeef8f31203c2f.pdf

[11]Elder, J. and Kennedy, P. E. (2001). Testing for Unit Roots: What Should Students Be Taught? Journal of Economic Education, Spring, 137-146.

https://doi.org/10.1080/00220480109595179

[12] Engle, R. F. and C. W. J. Granger (1987). Co-integration and Error Correction: Representation, Estimation and Testing. Econometrica, 55 , 251-276.

https://doi.org/10.2307/1913236

[13] Güleç, Ö. F., Çevik, E. ve Bahadır, N. (2018). Bitcoin ile Finansal Göstergeler Arasındaki İlişkinin İncelenmesi. Kırklareli Üniversitesi İktisadi ve İdari Bilimler Fakültesi Dergisi, 7(2), 18-37.

[14] Johansen, S. (1988). Statistical Anaylsis of Cointegrating Vectors. Journal of Economic Dynamics and Control. 12, 231 - 254. https://doi.org/10.1016/0165-1889(88)90041-3

[15] Kesebilir, M. ve Günceler, B. (2019). Kripto Para Birimlerinin Parlak Geleceği. Iğdır Üniversitesi Sosyal Bilimler Dergisi, 17, 605-625.

[16] Kremers, J. J., Ericsson, N. R. and Dolado, J. J. (1992). The Power of Cointegration Tests. https://www.bde.es/f/webbde/SES/Secciones/Publicaciones/PublicacionesSeriadas/DocumentosTrabajo/92/ Fich/dt_9218e.pdf, (Erişim Tarihi: 08.07.2019).

[17] Naimy V. and M. R. Hayek (2018). Modelling and predicting the Bitcoin volatility using GARCH models.International Journal of Mathematical Modelling and Numerical Optimisation 8(3):197.

[18] Ng, S. and Perron, P. (2001). Lag Length Selection and the Construction of Unit Root Tests with Good Size and Power. Econometrica, 69(6), 1519 - 1554.

https://doi.org/10.1111/1468-0262.00256 
[19] Öztürk, M. B., Arslan, H., Kayhan, T. ve Uysal, M. (2018). Yeni Bir Hedge Enstrumanı Olarak Bitcoin: Bitconomi. Ömer Halisdemir Üniversitesi İktisadi ve İdari Bilimler Fakültesi Dergisi, 11(2), 217-232.

[20] Phillips, P. C. B. and Perron, P. (1988). Testing for Unit Roots in Time Series Regression. Biometrika, 75, $335-346$.

https://doi.org/10.1093/biomet/75.2.335

[21] Şarkaya İçellioğlu, C. ve Engin Öztürk, M. B. (2018). Bitcoin ile Seçili Döviz Kurları Arasındaki İlişkinin Araştırılması: 2013-2017 Dönemi için Johansen Testi ve Granger Nedensellik Testi. Maliye ve Finans Yazıları, (109), 51-70.

https://doi.org/10.33203/mfy.343217

[22] Stavroyiannis S. and V. Babalos. (2017). Dynamic properties of the Bitcoin and the US market. https://ssrn.com/abstract=2966998

https://doi.org/10.2139/ssrn.2966998 